\title{
Öğrenme Stiline Dayalı Eğitimin Akademik Başarıya Etkisi“
}

\author{
Melih Dikmen $^{* * 1}$ ve Murat Tuncer ${ }^{2}$
}

$\ddot{O} z$

Anahtar Sözcükler

Öğrenme stilleri Akademik başarı Öğretmen eğitimi akademik başarıları üzerindeki etkisini incelemektir. Araştırmada öntest-sontest deney-kontrol gruplu yarı deneysel desen kullanılmıștır. Araștırmada veri toplama aracı olarak araștırmacılar tarafından geliştirilen Başarı Testi ile Riechmann ve Grasha tarafından geliştirilen ve Kılıç (2011) tarafından Türkçeye uyarlanan Grasha ve Riechmann Öğrenme Stilleri Ölçeği kullanılmıştır. Araştırmaya Fırat Üniversitesi Fen Bilgisi ve Türkçe Öğretmenliği lisans programındaki 109 öğretmen adayı (94 kadın ve 15 erkek) katılmıştır. Araştırmada, deney ve kontrol grupları yansız atama sonucunda oluşturulmuştur. Öğrenme stillerine dayalı öğretimin yapıldığı deney grubu öğretmen adaylarının akademik bașarılarının, kontrol grubu öğretmen adaylarına göre anlamlı düzeyde yüksek olduğu belirlenmiştir. Öğrenme stiline dayalı ögretimin, akademik başarı üzerinde orta düzeyde etki gücüne sahip olduğu görülmektedir. $\mathrm{Bu}$ doğrultuda öğretmen eğitimindeki niteliği artırmak amacıyla öğretmen adaylarının baskın öğrenme stillerinin dikkate alınması önemli bir değişken olarak görülebilir. Yükseköğretim kurumlarında öğretmen adaylarının öğrenme stillerine uygun öğretim programları hazırlanması ve uygulanması önerilmektedir.
Makale Hakkında

Gönderim Tarihi

27 Subat 2020

Kabul Tarihi

19 Haziran 2020

Makale Türü

Araştırma Makalesi

DOI:10.12984/egeefd.695452

\section{The Effect of Education Based on Learning Style on Academic Achievement}

\section{Abstract}

The purpose of this research was to examine the effects of teaching structured according to pre-service teachers' dominant learning styles on their academic achievement. Pre-test and post-test experimentalcontrol group quasi-experimental design was used in this research. The data of this research was gathered through the academic achievement test developed by the researchers, and the Grasha \& Riechmann Learning Styles Scale developed by Riechmann \& Grasha and adapted to Turkish by Kılıç (2011). The participants in this research were 109 pre-service teachers ( 94 females and 15 males) enrolled in the departments of Science Teaching and Turkish Language Teaching at Frat University. Experimental and control groups were formed as a result of unbiased appointment. It was determined that the academic achievement of the experimental-group for which the teaching was designed based on their dominant learning styles was higher than the control group. It is seen that teaching based on learning style has a medium level of effect on academic achievement. Accordingly, considering the dominant learning styles of pre-service teachers can be seen as an important variable in order to increase the quality in teacher education. In higher education institutions, it is recommended to prepare and implement curriculum suitable for pre-service teachers' learning styles.
Keywords

Learning styles Academic achievement

Teacher education

Article Info

Received

February 27, 2020

Accepted

June 19, 2020

Article Type

Research Paper

Atıf: Dikmen, M. ve Tuncer, M. (2020). Öğrenme stiline dayalı eğitimin akademik başarıya etkisi. Ege Eğitim Dergisi, 21(1), 71-88. doi:10.12984/egeefd.695452

\footnotetext{
* Bu araştırma 2019-2020 yılında Fırat Üniversitesi Eğitim Bilimleri Enstitüsünde yürütülen Doktora tezi kapsamında üretilmiştir. [This research was produced in the scope of the Ph.D. thesis carried out in Firat University Institute of Educational Sciences in 2019-2020.]

*** Sorumlu Yazar/Corresponding Author

1. (D) Frat Üniversitesi, Eğitim Fakültesi, Eğitim Bilimleri Bölümü, Türkiye, melihdikmen@ gmail.com

2 (D) Frrat Üniversitesi, Eğitim Fakültesi, Eğitim Bilimleri Bölümü, Türkiye, mtuncer@ firat.edu.tr
} 


\section{Extended Abstract}

\section{Introduction}

The desired education process depends on the effective and functional planning of many variables (Dikmen \& Tuncer, 2018). Some of these variables are how individuals think and learn (Altun, 2016). According to Tomlinson (2007), "individuals think, learn and produce differently from each other" (p. 38). For this reason, learning styles and strategies of individuals are seen as an important structure in considering individual differences within the education process. According to Kolb (1988), learning style is explained as the individual's personal preference in the process of receiving and processing information. According to Kefee (1979), learning style is explained by the learner as an indicator of psychological and emotional behaviors that constitute structures related to how learning environments are perceived and how they interact and react.

In order to increase the academic achievement of students, qualitative, quantitative, and experimental studies are carried out by many researchers (Aslandağ \& Çetinkaya, 2019; Başbuğ \& Adıgüzel, 2019; Yıldız \& Beşoluk, 2019). Students' academic achievements, problem solving skills, psychomotor performances, grade averages are some concrete indicators of whether or not learning occured (Brown, Cosgriff, \& French, 2008). Nowadays, there is an increase in the number of studies (Dikmen, Bahadır, \& Akmençe, 2018; Dikmen, Tuncer, \& Şimşek, 2018; Kaya \& Akçin, 2002; Puji \& Ahmad, 2016; Retrosi, Morris, \& McGavock, 2019; Süral \& Sarıtaş, 2015; Tuncer \& Dikmen, 2019; Tuncer, Dikmen, \& Akmençe, 2018) examining the relationship between academic achievement and dominant learning styles in higher education institutions. As in all levels of education, it is important for lecturers to know students' characteristics and learning styles in order to carry out an effective and efficient teaching process in higher education institutions (Choudhary, Dullo, \& Tandon, 2011). However, there are contradictory results in the literature regarding the relationship between learning styles and academic achievement (Dobson, 2010). In addition to all these situations, when the studies on learning styles in the literature are examined, it is seen that there are studies related to screening type and experimental studies are limited in number (Aşkın, 2006).

The focus of this research was to examine the effects of teaching structured according to pre-service teachers' dominant learning styles on their academic achievement Although there are several experimental studies in the literature that are structured according to dominant learning styles, the absence of experimental research designed on the academic achievements of pre-service teachers in terms of Grasha - Reichmann learning styles makes this research distinctive.

\section{Method}

In this research, pretest-posttest control group, experimental design was used. The participants were 109 preservice teacher (94 females and 15 males) enrolled in the departments of Science Teaching and Turkish Language teaching at Firat University. The research was conducted in two classes randomly assigned in two groups, one control group (CG) and one experimental group (EG). There were 53 students in experimental group and 57 students in control group. In the Experimental Group, the Teaching Principles and Methods course was structured according to the Grasha \& Riechmann Learning Styles. In the Control Group, the course was carried out using the methods and techniques that were appropriate for the content of the course, regardless of the dominant learning styles. In the research, the academic achievement test developed by the researchers and the Learning Styles Scale developed by Riechmann \& Grasha (1974) and adapted to Turkish by Kılıç (2011) were used as data collection tools. In the preparation of the achievement test, the subject content specified by the Council of Higher Education regarding the Teaching Principles and Methods course was taken into consideration.

\section{Findings}

In the research, it was investigated whether there is a statistically significant difference between the academic achievement of pre-service teachers according to their dominant learning styles. According to the results of Kruskal Wallis-H analysis, there is no statistically significant difference in terms of posttest scores related to the dominant learning styles of pre-service teachers $\left(x^{2}=2.374 ; p>.05\right)$. Researchers conducted Covariance (ANCOVA) analysis in order to examine the effect size of the experimental process in detail. Some preliminary assumptions (normality, linearity) of the covariance analysis were tested. When the presumptions of covariance are examined, it is determined that assumptions were met. When the groups' pretest was taken together, it was determined that the common effect of the group and pretest on the posttest dependent variable were not statistically significant $(F=.633 ; p>.05)$. When pretest scores were taken under control, it was found that the corrected posttest scores were statistically significant in terms of experimental and control groups $(F=11.827 ; p$ 
$<.05)$. Bonferroni test was performed to determine the statistically significant differences among the groups. According to the Bonferroni test, the corrected posttest averages were found to be in favor of the students in the experimental group. Considering Cohen's (1988) effect sizes $(\eta 2=$, low if $01, \eta 2=$, moderate if $06, \eta 2=, 14$ wide-high level effects), the experimental process has a high level of influence on academic achievement $(\eta 2=$, $10)$.

\section{Discussion and Conclusion}

The aim of this experimental research was to investigate the effects teaching designed according to pre-service teachers' dominant learning styles on their academic achievement. It has been determined that pre-service teachers' academic achievement did not differ significantly according to their dominant learning styles. Similar findings can be seen in the studies of Bahar and Sülün (2011), Bahar, Özen, and Gülaçtı (2009), and Akkoyunlu and Y1lmaz-Soylu (2008). Another finding of the research was that the academic achievement of students in the experimental group in which teaching was conducted based on their learning styles were significantly higher than the academic achievement of the control group students, where the lectures were carried out without any manipulation in the learning environment. The results of the research show that teaching based on learning style has a high level of effect on academic achievement. Similar results were observed in the studies conducted by Bayrak and Bayram (2012), Cengizhan (2007), Cengizhan (2008), Demir and Usta (2011), Elban (2018), EvinGencel (2008), Önder (2006), Özgen and Alkan (2014), Şeker and Yılmaz (2011), Yıldız-İkikardeş and Şentürk (2011). 


\section{Giriş}

Eğitim ve öğretim sürecinin istendik doğrultuda olabilmesi, birçok değişkenin etkili ve işlevsel olarak planlanmasına bağlıdır (Dikmen ve Tuncer, 2018). Bu değişkenlerden bazıları bireylerin nasıl düşündükleri ve nasıl öğrendikleridir (Altun, 2016). Tomlinson'a (2007) göre "bireyler birbirlerinden farklı bir biçimde düşünür, öğrenir ve üretirler” (s. 38). Bu bağlamda bireysel farklılıklar, öğrenme sürecini birey için en etkili ve verimli olacak biçimde düzenlemeyi ve buna yönelik öğretim ortamlarının hazırlanmasını gerekli kılmaktadır (Özgür, 2011). Öğrenme stili, bireysel farklılıkların dikkate alınması ve öğrenme sürecinin etkin bir biçimde yürütülmesinde karşılaşılabilecek sorunların bir kısmını çözüme kavuşturabilir (Güven ve Kürüm, 2006). Ayrıca aktif öğrenmenin önemine dikkat çeken yeni eğitim modellerinde, öğrenme stillerinin ön plana çıktığ görülmektedir (Altun, 2016)

Felder ve Silverman (1988) öğrenme stilini bireyin bilgiyi alma, depolama ve işleme sürecindeki karakteristik yapısı ile kişisel tercihi olarak tanımlarken, Dunn ve Dunn (1986) bireyin öğrenmeye yönelik tercihi olarak tanımlamaktadır. Kolb (1988) ise öğrenme stilini, bireylerin bilgiyi alma ve işleme sürecindeki kişisel tercihleri olarak ifade etmektedir. Keefe'ye (1979) göre öğrenme stili, öğrenenin öğrenme ortamlarını nasıl algıladığına, nasıl etkileşime girdiğine ve nasıl tepkiler verdiğine ilişkin yapıları oluşturan psikolojik ve duygusal davranışların göstergesidir. Öğrenme stiline ilişkin tanımların ortak noktası, bireyin öğrenme sürecindeki kişisel tercihi olduğu yönündedir.

Araştırmacılar ve kuramcılar eğitim sürecinde öğrenme stillerini dikkate alan ve öğretimi bu yönde temellendiren tasarımlar ortaya koymak amacıyla çeşitli modeller geliştirmişlerdir (Almigbal, 2015). Bu modeller arasındaki farklılıkların kuramsal ya da uygulamaya dair olduğu belirtilmiştir (Mihai, 2017). Coffield, Moseley, Hall ve Ecclestone (2004) öğrenme stilini tanımlayarak, 13 önemli modeli içeren 71 ölçme aracını 5'li bir sınıflandırma ile kategorize etmiştir. Bunlardan birincisi, Dunn ve Dunn, Gregorc, Bartlett, Betts, Gordon, Marks, Paivio, Richardson, Sheethan ve Torrance'un öğrenme stillerini kapsamaktadır. Bu gruptakiler bireylerin görsel, işitsel, kinestetik ve dokunsal unsurlara yönelik tercihlerini ortaya çıkarmaktadır. İkincisi yetenek örüntüleri de dâhil olmak üzere bilişsel yapıları içeren öğrenme stili modelleridir. Bunlar; Riding, Broverman, Cooper, Gardner ve diğ. Guilford, Holzman ve Klein Hudson, Hunt, Kagan, Kogan, Messick, Pettigrew ve Witkin'dir. Üçüncüsü öğrenme stilini, kişilik özelliklerine göre inceleyen modellerdir. Bunlar; Apter, Jackson, Myers - Briggs, Epstein ve Meier, Harrion-Branson, Miller tarafından geliştirilen modelleri kapsamaktadır. Dördüncüsü esnek bir şekilde istikrarlı öğrenme tercihlerini içeren yapıdaki modellerdir. Bunlar; Allinson ve Hayes, Herrmann, Honey ve Mumford, Kolb, Felder ve Silverman, Hermanussen, Wierstra, de Jong ve Thijssen, Kaufmann, Kirton ve McCarty öğrenme stili modelidir. Beşincisi öğrenme yaklaşımlarından, öğrenme stratejilerine, oryantasyonlarına ve anlayışlarına kadar uzanan geniş bir aralığı kapsayan modellerdir. Bunlar; Entwistle, Sternberg, Vermunt, Biggs, Conti ve Kolody, Grasha-Riechmann, Hill, Marton ve Saljö, McKenney ve Keen, Pask, Pintrich, Smith, Garcia ve McCheachie, Schmeck, Weinstein, Zimmerman ve Palmer, Whetton ve Cameron tarafından geliştirilen modellerdir. Araştırmalarda en çok kullanılan öğrenme stillerinin Kolb öğrenme stili (Aşkar ve Akkoyunlu, 1993; Lu, Jia, Gong ve Clark, 2007), Grasha ve Reichmann öğrenme stili (Bakır ve Mete, 2014; Kamışlı ve Özonur, 2019) ve Felder ve Silverman öğrenme stili (Özpolat ve Akar, 2009) olduğu görülmektedir.

Kolb'ün (1984) modeli, dört öğrenme stilinden oluşmaktadır. Bunlar; değiştiren, özümseyen, ayrıştıran ve yerleştiren olarak adlandırılmıştır (Evin-Gencel, 2006). Değiştiren öğrenme stilindeki bireylerin fikir üretme ve düşünme yetenekleri çok iyidir. "Fikirleri yapılandırırken duygu ve düşüncelerini göz önüne alırlar." (Kolb, 1984, s. 7). Özümseyen öğrenme stilindeki bireyler pratik değere dayanan yaklaşımlardan ziyade mantıksal olarak sağlam teorilere daha fazla ilgi duyarlar (Hein ve Budny, 2000; Kolb, 1984). Ayrıştıran öğrenme stilindeki bireyler, kavramlar yoluyla düşünerek ve yaparak öğrenirler. Problem çözme, mantıksal çözümleme, karar verme ve sistematik planlama temel özellikleri arasında yer alır (Kılıç, 2002; Kolb, 1984). Yerleştiren öğrenme stilindeki bireyler, başkalarının analizlerini kullanarak pratik ve deneyimsel bir yaklaşımı benimserler (Kolb, 1984).

Alanyazındaki çalışmalarda sıklıkla incelenen Grasha ve Reichmann öğrenme stilleri modeli ise Riechmann ve Grasha (1974) tarafından geliştirilmiş olup altı öğrenme stilini içermektedir. Bunlar; bağımlı, bağımsız, iş birlikli, rekabetçi, katılımcı ve kaçınandır. Bağımlı öğrenciler, ihtiyaç duydukları kadar öğrenirler. Öğretmenlerini ve meslektaşlarını bir yapı ve destek kaynağı olarak görmektedirler. Ne yapmaları gerektiğini belirlemek için otoriteye yönelirler. Bağımsız öğrenciler, kendi başlarına düşünmeyi ve öğrenme yeteneklerine güvenmeyi severler. Kendileri için önem taşıyan içeriği öğrenmek ve ödevler için diğer öğrencilerle çalışmaktansa, yalnız çalışmayı tercih ederler. Bağımsız düşünme, öğrenci merkezli ders planlama, bağımsız çalışma, kendi öğrenme hızına uygun öğretim akışı sağlayan projelerden hoşlanırlar. Katılımcı öğrenciler, sınıfta olmaktan ve olaylara mümkün olduğunca katılmaktan keyif alırlar. Sınıf ortamında kendilerine verilen görevleri elinden geldiği kadar yapmaya eğilimlidirler. Rekabetçi öğrenciler, sınıftaki arkadaşlarından daha iyi performans 
göstermek için sürekli bir çaba gösterirler. Bu öğrenme stilindeki bireyler, diğer öğrencilerden başarılı olduğunun fark edilmesinden, dikkat çekmekten hoşlandıkları gibi, verilecek ödülleri kazanmak için sürekli yarışmaları gerektiğini düşünürler. İş birlikli öğrenciler fikirlerini ve yeteneklerini paylaşmak isteyen öğrencilerdir. Öğretmenler ve diğer öğrencilerle işbirliği yapmaktan keyif alırlar. Genel sınıf tercihleri; küçük tartışma gruplarına sahip dersleri, küçük seminerleri, öğrenci merkezli dersleri ve grup projelerini içerir. Kaçınan öğrenme stilindeki öğrenciler, derslere katılmak konusunda hevesli değildirler. Öğretmenler ve akranlarıyla iş birliği yapmazlar. Okulda neler yapıldığına ilgi duymadıkları gibi bu ortamdan sıkıldıklarını hissederler (Riechmann ve Grasha, 1974).

Alanyazında sıklıkla incelenen bir diğer model olan Felder ve Silverman öğrenme stili modeli, 1988 yılında mühendislik fakültesinde öğrenim gören öğrencilerin öğrenme stili farklılıklarını belirlemek amacıyla geliştirilmiştir (Felder ve Spurlin, 2005). Bu model dört alt boyut ve dört alt boyuta ilişkin sekiz öğrenme stilinden oluşmaktadır (Felder, 2002). Bunlar; duyusal, sezgisel, görsel, işitsel, etkin, yansıtıcı, sıralı ve bütünsel olarak adlandırılmıştır. Felder ve Silverman öğrenme stilinin görsel ve işitsel boyutu, bilginin hem görsel hem de sözel olarak sunulmasının bireylerin öğrenmelerini en iyi şekilde oluşturabileceğini varsaymaktadır (Felder ve Silverman, 1988). Etkin boyutunda birey bilgiyi yaparak ve yaşayarak en iyi şekilde öğrenme ve anlama eğilimindedir (Graf, Viola ve Kinshuk, 2006). Yansitıcı boyutunda bireyler önce sessizce düşünmeyi tercih ederken, etkin boyutunda deneyerek ve sonuçlarını izleyerek öğrenmeyi tercih ederler (Bradford University, 2019). Sıralı öğrenme boyutunda öğrenciler bilgiyi birbirleriyle ilişkili küçük parçalar hâlinde almak isterler. Bütünsel öğrenme boyutunda ise öğrenciler birbirinden bağımsız olan bilgileri büyük parçalar hâlinde almayı tercih ederler.

Öğrencilerin akademik başarılarını artırmak amacıyla birçok araştırmacı (Başbuğ ve Adıgüzel, 2019; Aslandağ ve Çetinkaya, 2019; Yıldız ve Beşoluk, 2019) tarafından nitel, nicel ve deneysel çalışmalar yapılmaktadır. Öğrencilerin akademik başarıları, problem çözme becerileri, psikomotor performansları, not ortalamaları, öğrenmenin gerçekleşip gerçekleşmediğine dair bazı somut göstergeler olarak kabul edilebilir (Brown, Cosgriff, French, 2008). Bu göstergeler arasında yer alan akademik başarı ile baskın öğrenme stilleri arasındaki ilişkiye dair yapılan araştırmaların (Dikmen, Bahadır ve Akmençe, 2018; Dikmen, Tuncer ve Şimşek, 2018; Kaya ve Akçin, 2002; Puji ve Ahmad, 2016; Retrosi, Morris ve McGavock, 2019; Süral ve Sarıtaş, 2015; Tuncer ve Dikmen, 2019; Tuncer, Dikmen ve Akmençe, 2018 ) sayısının gitgide arttığı görülmektedir. Öğretimin her kademesinde olduğu gibi yükseköğretim kurumlarında da etkili ve verimli bir öğretimin gerçekleşmesi için öğretim elemanlarının, öğrencilerin özellikleri ile öğrenme stillerini bilmesi önemlidir (Choudhary, Dullo ve Tandon, 2011). Ancak, alanyazında öğrenme stilleri ile akademik başarı arasındaki ilişkiye dair çelişkili sonuçlar yer almaktadır (Dobson, 2010). Ayrıca alanyazında öğrenme stillerine yönelik araştırmalar incelendiğinde genellikle ilişkisel tarama türünde çalışmaların olduğu, deneysel çalışmaların ise sınırlı sayıda kaldığı görülmektedir (Aşkın, 2006). Uzuntiryaki, Bilgin ve Geban (2004) bireyin baskın öğrenme stilinin, akademik başarısı üzerinde güçlü bir etkiye sahip olduğunu belirtirken, Atalay ve Ay (2016) öğrenme stilinin akademik başarı üzerinde anlamlı bir değişken olmadığını saptamıştır. Ayrıca araştırmalar öğrenme stilleri ile öğrenmeye yönelik tutum (Dikmen, Tuncer ve Şimşek, 2018), ders çalışma alışkanlıkları (Başbay, 2013), kişilik tipleri (Kösece, Üredi ve Akbaşl1, 2015), öğretmenlik mesleğine yönelik tutum (Pehlivan, 2010), derse yönelik tutum, öğrenme motivasyonu (Azizoğlu ve Çetin, 2009), öğrenme alanı (Demir, 2008), eleştirel düşünme becerisi (Beşoluk ve Önder, 2010), akademik başarı (Bilgin ve Durmuş, 2003), liderlik yönelimi (Arslan ve Uslu, 2014), epistemolojik inanç (Huglin, 2003), üstbiliş düşünme becerisi (Zarrabi, 2017), öğrenme yaklaşımları (Ozan, Karabacak, Kızıltaş ve Küçükoğlu, 2017) ve akademik öz yeterlik (Miles, 2004) arasında istatistiksel olarak anlamlı düzeyde ilişki olduğunu ortaya koymuştur.

$\mathrm{Bu}$ araştırmada öğretmen adaylarının baskın öğrenme stillerine göre yapılandırılmış öğretimin akademik başarıları üzerindeki etkisi incelenmiştir. Her ne kadar alanyazında baskın öğrenme stillerine göre yapılandırılmış birkaç deneysel araştırma (Evin-Gencel, 2006; Usta, 2006) olsa da, Grasha - Reichmann öğrenme stilleri modeli açısından öğretmen adaylarının akademik başarıları üzerine tasarlanmış deneysel araştırmanın olmaması bu araştırmayı özgün kılmaktadır. Ayrıca, alanyazında Yükseköğretim Kurulu (YÖK) öğretmen yetiştirme lisans programlarındaki meslek bilgisi dersleri altında yer alan Öğretim İlke ve Yöntemleri dersinin, baskın öğrenme stillerine göre deneysel olarak herhangi bir araştırmada tasarlanmadığ 1 görülmektedir. Dolayısıyla bu araştırmadan elde edilecek bulgular öğretmen eğitimi programlarındaki öğretim sürecinin verimliliğini artırmaya katkı sunabilir.

\section{Arastırmanın Amacı ve Denencesi}

Tarih boyunca, araştırmacılar öğrenme paradigmaları kavramını anlamaya ve tahmin etmeye çalışmışlardır. Bireylerin bir derse yönelik akademik not ortalamaları, o derse ilişkin öğrenmenin gerçekleşip gerçekleşmediği fikrini oluşturabilir. Bu nedenle bireylerin baskın öğrenme stillerine göre yapılandırılmış öğretimin, akademik başarıyı etkileyip etkilemediğinin araştırılması öğretme ve öğrenme süreçleri açısından önemlidir. Bu doğrultuda 
araştırmanın amacı öğrenme stiline göre yapılandırılmış öğretim ilke ve yöntemleri dersinin öğretmen adaylarının akademik başarısına etkisini incelemektir.

Akademik başarı, eğitim ve öğretimin sonuçlarının değerlendirilmesinde dikkate alınan en önemli göstergelerden biridir (Shirazi ve Heidari, 2019). Bu nedenle baskın öğrenme stilleri ile akademik başarı arasındaki ilişki birçok araştırmacının (Hanafi, 2019; Singh, 2017; Vizeshfar ve Torabizadeh, 2018) çalışmalarına konu olmuştur. Araştırmaların sonuçları incelendiğinde baskın öğrenme stillerinin akademik başarı üzerinde etkili bir değişken olduğunu ortaya koyan araştırmaların sayısı, etkili olmadığını bildiren araştırmaların sayısından fazladır (Cevher, 2017). Baskın öğrenme stillerine göre yapılandırılmış öğretimin akademik başarı üzerindeki etkisinin, öğrenme stillerinden mi yoksa öğretim ortamının zenginleştirilmesinden mi kaynaklandığı tam olarak tespit edilemese de; öğrenme üzerinde katkısı olacağı düşünülmektedir. Bu doğrultuda araştırmanın denencesi aşağıdaki gibidir:

$\mathrm{H}_{1}$ : Öğretmen adaylarının baskın öğrenme stiline göre yapılandırılmış öğretim, geleneksel öğretime göre akademik başarı üzerinde istatistiksel olarak anlamlı farklılık oluşturmaktadır. Denenceye ilişkin teorik çerçeve Şekil 1'de gösterilmiştir.

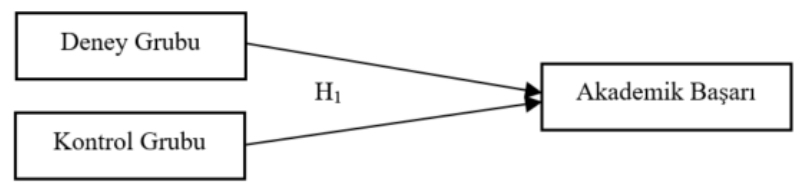

Şekil 1. $\mathrm{H}_{1}$ 'in Teorik Çerçevesi

Alanyazın incelendiğinde, araştırmaların baskın öğrenme stili ile akademik başarı arasındaki ilişkiye odaklandığı görülmektedir. Farklı öğrenme stillerindeki öğrencilerin akademik başarıları arasında istatistiksel olarak anlamlı düzeyde farklılık olup olmadığını inceleyen deneysel çalışmaların (Aşkın, 2006) ise sınırlı sayıda kaldığı söylenebilir. Ayrıca farklı baskın öğrenme stillerinin akademik başarıyı anlamlı biçimde farklılaştırıp farklılaştırmadığının belirlenmesi önemlidir. Felder ve Henriques (1995) farklı öğrenme stillerinin bir arada kullanılmasının akademik başarı üzerinde önemli bir etkisinin olabileceğini belirtmiştir. Bu doğrultuda Öğretmen adaylarının akademik başarlları, tercih ettikleri öğrenme stillerine göre anlamlı düzeyde farklılaştırmakta mıdır? biçiminde oluşturulan araştırma sorusuna ilişkin teorik çerçeve Şekil 2'de gösterilmiştir.

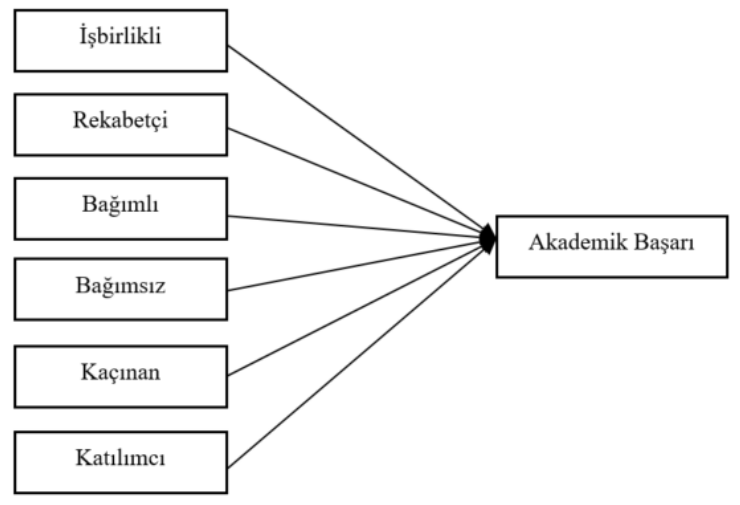

Şekil 2. Araştırma Sorusuna İlişkin Teorik Çerçeve

Şekil 2'de görüldüğü üzere, araştırmada deney grubundaki öğretmen adaylarının Öğretim İlke ve Yöntemleri dersindeki akademik başarılarının tercih ettikleri ögrenme stillerine göre anlamlı düzeyde farklılık gösterip göstermediği incelenmiştir.

\section{Yöntem}

\section{Araştırmanın Deseni}

$\mathrm{Bu}$ araştırmada yarı deneysel desenlerden öntest-sontest kontrol gruplu desen kullanılmıştır. Karasar (2009), bu deseni "gelişigüzel seçilmiş ve başlangıçta benzerlikleri bilinmeyen bir bölüm öğrencilerinin bulunduğu iki gruptan birinin deney diğerinin kontrol grubu olarak seçilmesi” (s. 96) şeklinde açıklamaktadır. Araştırma deseninin simgesel ifadesi Şekil 3'te sunulmuştur. 


\begin{tabular}{lccc}
\hline Grup & Veri Toplama Araçları Ön Uygulama & İşlem & Veri Toplama Araçları Son Uygulama \\
\hline Deney & $\mathrm{O}_{1}$ & $\mathrm{X}$ & $\mathrm{O}_{2}$ \\
Kontrol & $\mathrm{O}_{1}$ & & $\mathrm{O}_{2}$ \\
\hline
\end{tabular}

$\mathrm{O}_{1}$ : Uygulama öncesi veri toplama araçlarının uygulanması

$\mathrm{O}_{2}$ : Uygulama sonrası veri toplama araçlarının uygulanması

X: Grasha-Reichmann Öğrenme Stiline göre yapılandırılmış öğrenme yaşantılarına uygun olarak dersin işlenmesi

\section{Şekil 3. Deneysel Desenin Simgesel Olarak Gösterimi}

Şekil 3’te görüldüğü üzere, deney ve kontrol grubundaki öğretmen adaylarına deneysel işleme başlamadan önce veri toplama araçlarının ön uygulaması yapılmıştır. Deney grubunda Grasha-Reichmann öğrenme stilleri ölçeği aracılığıyla belirlenen baskın öğrenme stillerine göre yapılandırılmış Öğretim İlke ve Yöntemleri dersi yürütülmüştür. Kontrol grubunda ise öğrencilerin baskın öğrenme stilleri dikkate alınmaksızın YÖK tarafindan belirlenen Öğretim İlke ve Yöntemleri dersinin içeriğine uygun yöntem ve teknikler kullanılarak yürütülmüştür. Her iki grupta kullanılan öğretim yöntem ve teknikleri veri toplama süreci başlı̆̆ı altında ayrıntılı olarak açıklanmıştır.

\section{Calıșma Grubu}

Araştırma Fırat Üniversitesi Eğitim Fakültesi Fen Bilgisi Öğretmenliği ve Türkçe Öğretmenliği lisans programlarında öğrenim gören öğretmen adaylarının katılımıyla yürütülmüştür. Çalışma grubu 109 öğretmen adayından oluşmaktadır. Araştırmaya Türkçe Öğretmenliği lisans programından 55, Fen Bilgisi Öğretmenliği lisans programından ise 54 öğretmen adayı katılmıştır. Katılımcıların 94'ü (\% 86.2) kadın, 15’i (\% 13.8) erkektir. Katılımcıların yaş düzeyi 19 ila 23 arasında değişmektedir. Araştırmada, kura yoluyla iki grup oluşturulmuştur. Daha sonra bu gruplar rastgele deney ve kontrol grubu şeklinde atanmıştır. Deney grubunda 53 öğretmen adayı, kontrol grubunda ise 56 öğretmen adayı yer almaktadır. Kontrol grubu Türkçe Öğretmenliği lisans programından 29, Fen Bilgisi Öğretmenliği lisans programından ise 27 öğretmen adayından oluşmaktadır. Deney grubunda ise Türkçe Öğretmenliği lisans programından 26, Fen Bilgisi Öğretmenliği lisans programından 27 öğretmen adayı yer almaktadır.

\section{Veri Toplama Araçları}

Araştırmada öğretmen adaylarının Öğretim İlke ve Yöntemleri dersindeki akademik başarılarını ölçmek için araştırmacılar tarafindan geliştirilen başarı testi kullanılmıştır. Başarı testinin hazırlanmasında YÖK'ün Öğretim İlke ve Yöntemleri dersine yönelik içeriği dikkate alınmıştır. YÖK'ün belirttiği konu başlıklarında genel ifadeler yer aldığından, ders içeriğinin ve kazanımların hazırlanmasında üç uzman görüşü ve ilgili derse yönelik hazırlanmış kitaplardan faydalanılmıştır. Bu doğrultuda 68 kazanım oluşturulmuş ve bu kazanımlara yönelik 50 soru hazırlanmıştır. Hazırlanan soruların ilgili kazanımı ölçüp ölçmediğini belirlemek amacıyla üç uzmandan görüş alınmıştır. Uzman görüşü sonucunda gerekli düzeltmeler yapılarak kapsam geçerliği sağlanmaya çalışılmıştır. 50 sorudan oluşan Öğretim İlke ve Yöntemleri Başarı Testinin (ÖIYBT) ilk hali Fen Bilgisi ve Türkçe Öğretmenliği lisans programındaki 4. sınıf öğrencilerinden oluşan 98 kişilik gruba ön uygulaması yapılmıştır. Baykul (2000) "gruplara (üst ve alt) göre madde analizi yapıldığı durumlarda en az 100 tercihen 200 civarında cevaplayıcının yeterli olacağını" (s. 330) belirtmiştir. Atılgan (2006) ise "deneme grubunun büyüklüğü konusunda nihai testin uygulanacağı kişi sayısı ve olanaklar (uygulamadaki kişi sınırı) gibi iki ölçütün birlikte değerlendirilmesi gerektiğine" (s. 321) dikkat çekmiştir. Bu iki görüş açısından bir değerlendirme yapıldığında 98 kişilik deneme formu uygulamasının yeterli olduğu söylenebilir. Ön uygulama yapılmadan önce öğretmen adaylarına araştırma hakkında ön bilgilendirme anlatılmış olup başarı testinin araştırmadaki öneminden bahsedilmiştir. Başarı testi için ön uygulamada öğretmen adaylarına 75 dakika süre verilmiştir. Ön uygulama sonucunda her bir madde üzerinde ayırt edicilik ve güçlük indeksleri hesaplanmıştır. Madde ayırt edicilik indeksi .29'un altında olan maddeler bilenle bilmeyeni ayırt edemeyeceğinden dolayı (Tekin, 2010) testten çıkarılmıştır. Araştırmadaki maddelerin ayırt edicilik indeksleri .30 ile .63 arasında değişmektedir. Başarı testinin son hali 30 maddeden oluşmaktadır. Başarı testi üzerinde son olarak testin iç tutarlılığını ölçmek amacıyla KR-20 (KuderRichardson) değeri hesaplanmış ve .73 olarak bulunmuştur. Ayrıca Madde Toplam Varyansı 9.45 ve Ortalama Güçlük Düzeyi .57 olarak hesaplanmıştır. Ön uygulama sonunda öğretmen adaylarının hangi soruya kadar gelebildikleri ve soruları çözme hızları gibi durumlar değerlendirilmiştir. Ayrıca uygulama sonunda bazı öğrencilerin görüşleri alınmıştır. Yapılan görüşmeler neticesinde sürenin yeterli olduğu ve testin çok zor olmadığı bilgisine ulaşılmışıtır. Bu doğrultuda başarı testinin araştırmada kullanılması uygun görülmüştür.

Öğretmen adaylarının baskın öğrenme stillerini tespit etmek amacıyla kullanılan Grasha ve Riechmann Öğrenme Stilleri Ölçeği altmış maddeden oluşmaktadır. Maddeler, 1 (kesinlikle katılmıyorum) ile 5 (kesinlikle katılıyorum) arasında değişen beşli likert tipindedir. Grasha ve Riechmann Öğrenme Stilleri Ölçeği yedi öğrenme stilinden oluşmaktadır. Bunlar; Bağımsız, Bağımlı, İş birlikli, Rekabetçi, Paylaşımcı ve Kaçınan öğrenme stilleridir. Ölçekte, her bir öğrenme stili için on madde yer almaktadır. Her öğrenme stili düşük, orta ve 
yüksek olmak üzere üç dereceden oluşmaktadır. En yüksek ortalamaya sahip boyut bireyin baskın öğrenme stilini göstermektedir. Araştırmada kullanılan Grasha ve Riechmann Öğrenme Stilleri Ölçeği, K1lıç (2011) tarafından Türkçeye uyarlanmıştır. Kılıç (2011) tarafından yapılan geçerlik çalışmasında ölçeğin Türkçe dil eşdeğerliği sağlandıktan sonra, kapsam ve görünüş geçerliği için uzman görüşüne sunulduğu belirtilmiştir. Bu görüşler doğrultusunda ölçekteki eksiklikler giderilerek, bazı maddeler üzerinde sadeleştirmeler yapıldığı bildirilmektedir. Ölçeğin yapı geçerliğini ortaya koymak amacıyla açımlayıcı faktör analizi yapılmıştır. Üç yüz altı katılımcıdan elde edilen verilerin faktör analizi yapılmasına uygun olduğu belirlenmiştir $\left(K M O=0.88 ; X^{2}=\right.$ 8488.42; $s d=1770 ; p=0.00)$. Varimax rotasyon yöntemi sonucunda, ölçeğin toplam varyansın \% 32.81'ini açıkladığını ve öz değeri 1'in üzerinde olan 6 faktörlü bir yapı elde edilmiştir. Faktörlerde yer alan madde yük değerleri .31 ile .72 arasında değişmektedir. Araştırmada öğretmenlerin öğrenme stillerini belirlemek amacıyla ölçeğin maddeleri geçmiş zamanla ifade edilerek uygulandığı belirtilmektedir (örneğin, "Ders sırasında küçük grup aktivitelerine dâhil olmaktan zevk alırdım.”) (Kılıç, 2011). Riechmann ve Grasha (1974) ölçeğin üniversite öğrencileri için kullanılmasının uygun olduğunu belirtmektedir. Altun (2016) da, Grasha-Reichmann Öğrenme Stili Ölçeğinin genellikle lise ve üniversite düzeyinde öğrenim gören bireylerin baskın öğrenme stillerini belirlemek amacıyla geliştirildiğini ifade etmektedir. Ayrıca farklı kültürlerde yapılan araştırmalarda da (Baneshi, Karamdoust ve Hakimzadeh, 2013) ölçeğin üniversite öğrencileri üzerinde uygulandığ 1 görülmektedir. Yurt içinde farklı araştırmacılar (Sarıtaş ve Süral, 2010; Uzuntiryaki, Bilgin ve Geban, 2003) tarafından öğretmen adayları üzerinde geçerlik ve güvenirliği test edilen Grasha ve Riechmann Öğrenme Stilleri Ölçeğine ilişkin bulguların, Kılıç (2011) tarafından elde edilen sonuçlarla örtüştüğü görülmektedir. Kılıç (2011) test-tekrar test yöntemiyle, ölçeğin alt boyutlarına ilişkin güvenirlik değerlerini; bağımsız boyutu için .91, kaçınan boyutu için .92 , iş birlikli boyutu için .90 , bağımlı boyutu için .92 , rekabetçi boyutu için .93 , katılımcı boyutu için .89 ve ölçeğin tamamı için .91 olarak hesaplamıştır. Bu araştırma kapsamında ölçekten elde edilen veriler üzerinde hesaplanan Cronbach alfa iç tutarlılık katsayısı .73 olarak bulunmuştur. Bu bağlamda, ölçeğin güvenilir bir ölçek olduğu sonucuna varılabilir. Bu bulgular doğrultusunda ölçeğin araştırmada kullanılmasının uygun olduğuna karar verilmiştir.

\section{Veri Toplama Süreci}

Veri toplama sürecinin ikinci aşamasında YÖK tarafından hazırlanan Öğretim İlke ve Yöntemleri dersinin içeriği incelenmiştir. YÖK, Öğretim İlke ve Yöntemleri dersinin içeriğini 7 başlık altında ele almıştır. Bu başlıkların eğitim ve öğretimle ilgili temel kavramlar, öğrenme ve öğretim ilkeleri, öğretimin planlanması, öğretimde planlı çalışmanın önemi ve yararları, öğrenme, öğretim stratejileri, yöntem ve teknikleri, öğretim araç ve gereçleri, öğretim hizmetinin niteliğini artırmada öğretmenin görev ve sorumlulukları ve öğretmen yeterlikleri olduğu görülmektedir (YÖK, 2019). Bu konu başlıkları doğrultusunda uzman görüşü alınarak kazanımlar belirlenmiş̧tir. 7 ana başlık için 68 kazanım oluşturulmuştur. Baskın öğrenme stiline göre yapılandırılmış öğretimin, uygunluğuna ilişkin 3 alan uzmanının görüşü alınmıştır. Öğretim etkinliklerinin planlanmasında Grasha ve Riechmann tarafından bağımlı, bağımsız, katılımcı, rekabetçi, iş birlikli ve kaçınan öğrenme stilindeki öğrencilerin özellikleri dikkate alınmıştır. Bu doğrultuda bağımsız öğrenme stilindeki öğretmen adayları için yapılandırılan öğretim etkinlikleri genellikle bireysel çalışmaları içermiştir. Bağımlı öğrenme stilindeki öğretmen adaylarına yönelik öğretim etkinliklerinin temelini öğretim elemanı tarafından yapılan açık ve net yönergeler oluşturmaktadır. Yani öğretim elemanı bu öğrenme stilindeki öğretmen adayları için bir kılavuz rolünde olmuştur. Katılımcı öğrenme stilindeki öğretmen adaylarına ilişkin öğretim etkinliklerinde aktif katılımın sağlanabileceği (gösterip yaptırma yöntemi, panel tekniği, forum tekniği ve seminer tekniği) ders ortamı oluşturulmuştur. Kaçınan öğrenme stilindeki öğretmen adaylarının öğrenme özellikleri doğrultusunda ödev ve rapor hazırlanması gibi öğretim etkinliklerine sıklıkla başvurulmuştur. İş birlikli öğrenme stilindeki öğretmen adayları için sınıf içi ve sınıf dışı aktivitelerde genellikle grup çalışmalarını içeren öğretim etkinlikleri yapılmıştır. Rekabetçi öğrenme stilindeki öğretmen adayları için ise sınıf ortamında sürekli bir rekabet ortamının oluşturulmasına yönelik etkinliklerin uygulanabileceği yöntem ve teknikler (beyin firtınası, münazara ve fikir taraması tekniği) kullanılmıştır. Öğretim İlke ve Yöntemleri dersi deney ve kontrol gruplarında aynı öğretim elemanı tarafindan yürütülmüştür. Araştırma bir eğitim-öğretim dönemi (12 hafta) boyunca yürütülmüştür. Tablo 1 'de ögretimle ilgili temel kavramlar konusu için uygulanan etkinlik örnekleri sunulmuştur. 
Tablo 1

Öğretimle İlgili Temel Kavramlar Konusuna Yönelik Örnek Öğretim Etkinliği

\begin{tabular}{|c|c|}
\hline Baskın Öğrenme Stili & Öğretim Etkinliği \\
\hline Rekabetçi & $\begin{array}{l}\text { Eğitim ve öğretim kavramlarını zihinlerinde çağrıştırdıkları tek bir kelime ile ifade etmeleri } \\
\text { istenir. Rekabetçi öğrenme stiline sahip öğrencilerin birbirleri içerisinde yarışmaları amacıyla en } \\
\text { hızlı ve doğru sonuca ulaşan öğrencinin ödüllendirileceği vurgulanır. }\end{array}$ \\
\hline İş birlikli & $\begin{array}{l}\text { Öğrenmenin ön koşullarının her bir aşamasını ve öğrenme sürecini drama yöntemiyle sınıfta } \\
\text { sergilemeleri istenir. Drama yönteminde yer alacak öğrenciler öğretim elemanı tarafından iş } \\
\text { birlikli öğrenme stiline sahip öğrencilerden seçilir. }\end{array}$ \\
\hline Kaçınan & $\begin{array}{l}\text { Eğitim ve türlerini araştırarak elde ettikleri bilgileri haftaya el yazısı halinde kâğıda geçirilmiş } \\
\text { bir biçimde öğretim elemanına getirmeleri istenir. }\end{array}$ \\
\hline Katılımc1 & $\begin{array}{l}\text { Öğrenme süreçlerine ilişkin örnek durumlar vermeleri istenir. Ayrıca katılımcı öğrenme stiline } \\
\text { sahip bireylerin kendi veya etrafındaki bireylerin yaşantılarından öğrenme sürecine ilişkin örnek } \\
\text { olaylar anlatmaları istenir. }\end{array}$ \\
\hline Bağımlı & $\begin{array}{l}\text { Öğretim elemanı tarafından yazılı olarak verilen örnek olayların içerisinde öğrenmenin ön } \\
\text { koşullarının sağlanıp sağlanmadığına ilişkin gerekçeli yorumlar yaparak bir sonraki hafta sınıf } \\
\text { ortamında nedenleriyle birlikte açıklamaları istenir. }\end{array}$ \\
\hline Bağımsız & $\begin{array}{l}\text { Eğitim, öğretim ve öğrenme kavramları arasındaki ilişkiye yönelik araştırma yaparak bir sonraki } \\
\text { hafta sınıfta sunmaları istenir. }\end{array}$ \\
\hline
\end{tabular}

Kontrol grubunda ise dersin içeriğine göre farklı öğretim yöntem ve teknikleri kullanılmıştır. Bu yöntem ve teknikler Öğretim İlke ve Yöntemleri dersinin YÖK’te belirtilen ders içeriğine uygun olarak seçilmiştir. Bu doğrultuda ĕgitim ve ögretimle ilgili temel kavramlar konusunda anlatım yöntemi, öğrenme ve ögretim ilkeleri konusunda anlatım yöntemi, tartışma yöntemi ve soru cevap tekniği, ögretimin planlanması, ögretimde planlı çalışmanın önemi ve yararları konusunda anlatım yöntemi ve tartışma yöntemi, ögrenme, öğretim stratejileri, yöntem ve teknikleri konusunda anlatım yöntemi, tartışma yöntemi, soru cevap tekniği, proje yöntemi, örnek olay yöntemi, gösterip yaptırma yöntemi, drama tekniği, istasyon tekniği, görüş geliştirme tekniği, kart eşleştirme tekniği ve kavram haritaları yöntemi, ögretim araç ve gereçleri konusunda anlatım yöntemi, tartışma yöntemi ve soru cevap tekniği, ögretim hizmetinin niteliğini artırmada öğretmenin görev ve sorumluluklarl konusunda anlatım yöntemi, tartışma yöntemi, örnek olay yöntemi ve soru cevap tekniği, öğretmen yeterlikleri konusunda ise anlatım yöntemi, tartışma yöntemi ve soru cevap tekniği kullanılmıştır.

Araştırmadaki deney ve kontrol gruplarındaki öğretmen adaylarına ÖIYBT’ye ilişkin sontest uygulanarak deneysel süreç bitirilmiştir. Daha sonra verilerin analizi kısmına geçilmiştir.

\section{Verilerin Analizi}

Araştırmada elde edilen veriler SPSS (Statistical Package for Social Sciences) for Windows 21.0 programı kullanılarak analiz edilmiştir. Verilerin analizinde tanımlayıcı istatistiksel metotlar (sayı, yüzde, ortalama, standart sapma) kullanılmıştır. Araştırmada deney ve kontrol grubu öğretmen adaylarının öntest puanları arasında istatistiksel olarak anlamlı farklılık $(p>.05)$ olmadığı belirlenmiştir. Kovaryans analizi ile daha hassas ölçümler yapılmaktadır. Ayrıca Kovaryans analizinin öntestten kaynaklanan farklılığı dikkate alması nedeniyle (Howitt ve Cramer, 1997) bu araştırmada kullanılmak istenmiştir. Kovaryans analizi yapılabilmesi için bazı varsayımların (normallik ve doğrusallık) karşılanmış olması gerekir (Taşpınar, 2017). Bu doğrultuda kontrol (öntest) ve bağımlı (sontest) değişkene ilişkin basıklık ve çarpıklık değerleri incelenmiştir. kontrol değişkenine ait (öntest) çarpıklık [.129 ile .231] ve basıklı̆̆ın [1.012 ile .459] arasında değer aldı̆̆ 1 , bağımlı değişkenin çarpıklık değeri [-.418 ile .231] ve basıklık değerinin ise [-.334 ile .459] arasında yer aldığı görülmüştür. George ve Mallery’a (2003) göre çarpıklık ve basıklık değerlerinin (+2) / (-2) arasında olması dağılımın normalliğinin göstergesidir. Ayrıca öntest ve sontest puan ortalamalarına ilişkin dağılımın normalliğinin belirlenmesi amacıyla histogram grafikleri çıkarılarak Şekil 4'te verilmiştir. 

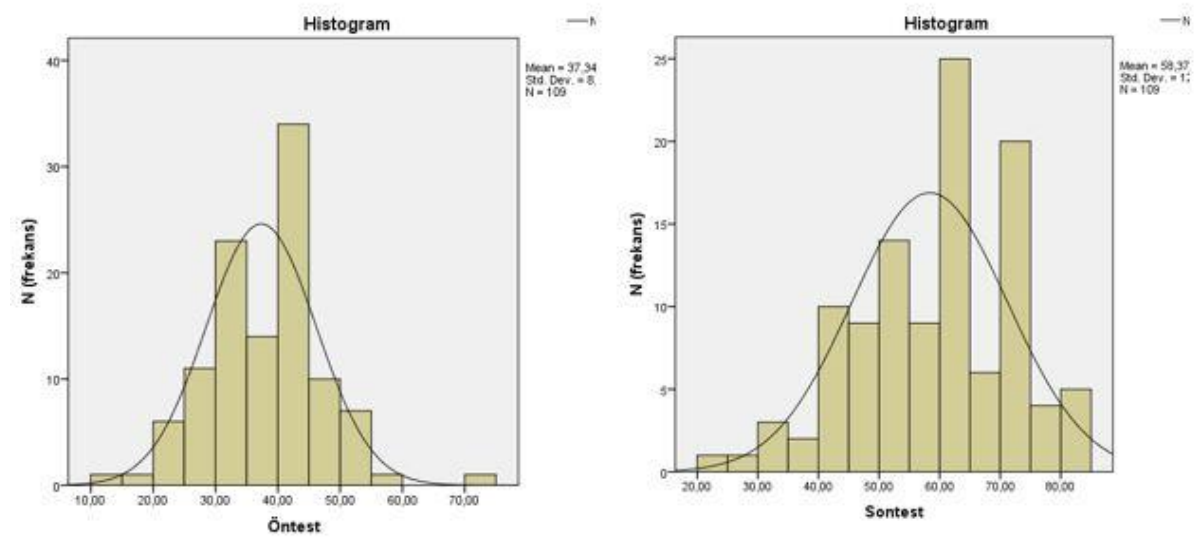

Şekil 4. Başarı Öntest ve Sontest Puanlarının Dağılımının Normalliğine İlişkin Histogram Grafiği

Şekil 4'te görüldüğü üzere öntest ve sonteste ait histogramlar incelendiğinde dağılımın normal olduğu söylenebilir. Kovaryans analizinin diğer bir ön sayıltısı ise bağımlı (sontest) ve bağımsız (öntest) değişken arasında doğrusal ilişkinin olmasıdır. Bu duruma yönelik Scatter plot grafiği incelenerek Şekil 5 'te verilmiştir.

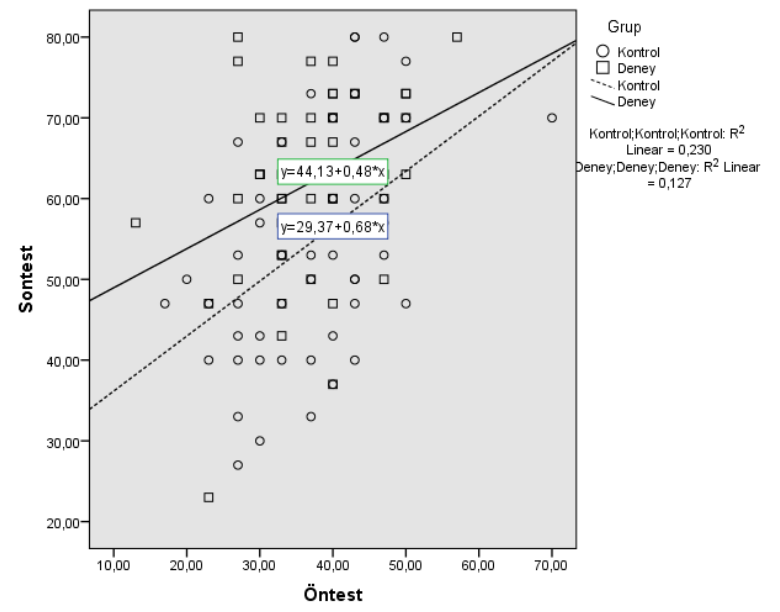

Şekil 5. Bağımlı (Sontest) ve Bağımsız (Öntest) Değişken Arasındaki Doğrusal İlişkiye Yönelik Grafik

Şekil 5'te görüldüğü üzere bağımlı (sontest) değişken ile kontrol (öntest) değişkeni arasında doğrusal bir ilişkinin olduğu belirlenmiştir. Ayrıca grafiğin sağ tarafında belirme (determinasyon) katsayıları incelendiğinde, kontrol grubundaki öğretmen adaylarının başarı sontesti puan ortalamalarının \% 23'ünün, öntest puanlarındaki değişimden kaynaklandığı görülmektedir. Benzer biçimde deney grubundaki öğretmen adaylarının başarı sontesti puan ortalamalarının \% 12.7'sinin, öntest puanındaki değişimden etkilendiği görülmektedir. Kovaryans analizi sonucunda hesaplanan etki büyüklüklerinin değerlendirilmesinde Cohen'in (1988) $\left(\eta 2=.01\right.$ ise düşük. $\eta^{2}$ $=.06$ ise orta düzey. $\eta^{2}=.14$ yüksek düzey etki) aralıkları dikkate alınmıştır.

Deney grubundaki öğretmen adaylarının baskın öğrenme stillerine göre akademik başarılarının karşılaştırılması amacıyla Kruskal Wallis-H Testi kullanılmıştır. Russell ve Purcell (2009) parametrik testlerin kişi sayısı 30'dan düşük grupların karşılaştırılmasında kullanılmaması gerektiğini belirtmektedir. Benzer şekilde Gosling (2004) grubun, merkezi limit teoreminin uygulanamayacağı kadar küçük olduğu $(n<30)$ durumlarda, normallik sayıltısının yeterli düzeyde karşılanamayacağını belirtmiştir. Bu bağlamda baskın öğrenme stillerine düşen frekansların 30'un altında olması nedeniyle parametrik olmayan analizlerden Kruskal Wallis-H Testi kullanılmıştır.

\section{Etik Konular}

Fırat Üniversitesi Etik Kurulu'ndan onay alınmasından sonra araştırma yapılmıştır. Araştırmada yer alan deney ve kontrol gruplarındaki öğretmen adaylarına öğrenme stillerine ilişkin yürütülecek deneysel işlemden bahsedilmiş olup deneysel sürece başlamak için onayları alınmıştır. 


\section{Bulgular}

Araştırmada ilk olarak deney ve kontrol gruplarının başarı öntest ve sontest puan ortalamaları ve standart sapma değerleri hesaplanarak Tablo 2'de verilmiştir.

Tablo 2

Deney ve Kontrol Gruplarına Ilişskin Sontest Puan Ortalamaları

\begin{tabular}{lccccccc}
\hline \multirow{2}{*}{ Grup } & \multirow{2}{*}{$n$} & \multicolumn{2}{c}{ Öntest } & \multicolumn{2}{c}{ Sontest } & \multicolumn{2}{c}{ Düzeltilmiş Sontest } \\
\cline { 3 - 7 } & & $\bar{X}$ & $S S$ & $\bar{X}$ & $S S$ & $\bar{X}$ & $S S$ \\
\hline Kontrol & 56 & 37.21 & 9.41 & 54.70 & 13.34 & 54.77 & 1.50 \\
Deney & 53 & 37.47 & 8.28 & 62.25 & 11.24 & 62.17 & 1.54 \\
\hline
\end{tabular}

Tablo 2'de görüldüğü üzere kontrol grubu öğretmen adaylarının başarı öntestine ilişkin puan ortalamalarının (37.21 \pm 9.41) olduğu görülürken, başarı sontestine ilişkin puan ortalamalarının $(54.70 \pm 13.34)$ olduğu belirlenmiştir. Deney grubu öğretmen adaylarının başarı öntest puanları incelendiğinde (37.47 \pm 8.28$)$ düzeyinde olduğu, sontest puanlarının ise $(62.25 \pm 11.24)$ düzeyinde olduğu tespit edilmiştir. Ayrıca deney ve kontrol grupları için Kovaryans analizi için hesaplanan düzeltilmiş başarı sontest puanları incelendiğinde; kontrol grubu ögretmen adaylarının (54.77 \pm 1.50$)$ düzeyinde, deney grubu öğretmen adaylarının ise (62.17 \pm 1.54$)$ düzeyinde olduğu belirlenmiştir.

Deney ve kontrol gruplarına ilişkin öntest, sontest ve düzeltilmiş sontest puanları incelendikten sonra $\mathrm{H}_{1}$ denencesi sınanmıştır. Deneysel işlemin etki gücünü daha ayrıntılı bir biçimde incelenmesi amacıyla yapılan Kovaryans (ANCOVA) analizinin sonuçları Tablo 3 'te verilmiştir.

Tablo 3

Deney ve Kontrol Gruplarının Başarı Öntestlerinin Kontrol Altına Alınmast Sonucunda Başarı Sontestlerinin Karşılaştırılmasına İlişkin Kovaryans Analiz Sonuçları

\begin{tabular}{lccccccc}
\hline Varyansın Kaynağı & $K T$ & $s d$ & $K O$ & $F$ & $p$ & $\begin{array}{c}\text { Fark } \\
\text { Bonferroni }\end{array}$ & $\eta^{2}$ \\
\hline Öntest & 3008.13 & 1 & 3008.13 & 23.896 & .000 & & .184 \\
Grup*Öntest & 79.97 & 1 & 79.97 & .633 & .428 & & .100 \\
Grup & 1488.79 & 1 & 1488.79 & 11.827 & .001 & $1>2$ & \\
Hata & 13343.52 & 106 & 125.88 & & & & \\
Toplam (düzeltilmiş) & 17903.32 & 108 & & & & & \\
\hline
\end{tabular}

1: Deney; 2: Kontrol

Tablo 3'te görüldüğü üzere Grup*Öntest birlikte ele alındığında, sontest bağımlı değişkeni üzerinde grup ve öntestin ortak etkisinin anlamlı bir farklılık oluşturmadığı belirlenmiştir $(F=.633 ; p=.428>.05)$. Öntest puanları kontrol altına alındığında deney ve kontrol grubu açısından düzeltilmiş başarı sontest puanlarının istatiksel olarak anlamlı olduğu tespit edilmiştir $(F=11.827 ; p<.05)$. Tespit edilen anlamlı düzeydeki farklılığın hangi gruplar arasında olduğunun belirlenmesi amacıyla Bonferroni testi yapılmıştır. Bonferroni testine göre, düzeltilmiş başarı sontest ortalamalarının deney grubu öğrencilerinin lehine yüksek olduğu belirlenmiştir. Cohen'in (1988) etki büyüklükleri dikkate alındığında deneysel işlemin akademik başarı üzerinde orta düzeyde etki gücüne sahip olduğu söylenebilir $\left(\eta^{2}=.10\right)$.

Araştırmanın alt problemi doğrultusunda deney grubundaki öğretmen adaylarının tercih ettikleri baskın öğrenme stillerine göre akademik başarıları karşılaştırılmıştır. Elde edilen bulgular Tablo 4’te verilmiştir.

Tablo 4

Öğretmen Adaylarının Baskın Öğrenme Stillerine Göre Akademik Başarılarının Farklılaşıp Farklılaşmadĭ̆ını Belirlemek Üzere Yapılan Kruskal Wallis-H Testi Sonuçları

\begin{tabular}{|c|c|c|c|c|c|}
\hline Öğrenme Stilleri & $n$ & $\bar{X}$ & $\chi^{2}$ & $s d$ & $p$ \\
\hline Bağımlı & 8 & 23.88 & \multirow{6}{*}{2.374} & \multirow{6}{*}{5} & \multirow{6}{*}{.795} \\
\hline Bağımsız & 11 & 31.18 & & & \\
\hline İş birlikli & 13 & 24.85 & & & \\
\hline Rekabetçi & 10 & 29.45 & & & \\
\hline Katılımc1 & 9 & 23.72 & & & \\
\hline Kaçınan & 2 & 33.00 & & & \\
\hline
\end{tabular}


Tablo 4'te görüldüğü üzere öğretmen adaylarının baskın öğrenme stillerine göre Öğretim İlke ve Yöntemleri dersine ilişkin başarı sontest puanları arasında anlamlı farklılık bulunmamıştır $\left(x^{2}=2.374 ; p>.05\right)$. Sinıf ortamında farklı öğrenme stiline göre yapılan etkinliklerin deney grubundaki öğretmen adaylarının tamamına katkı sunmuş olabilir. Dolayısıyla bu durum, farklı öğrenme stillerindeki öğretmen adaylarının benzer akademik başarıya sahip olmasına neden olmuş olabilir.

\section{Sonuç ve Tartışma}

Bu araştırmada öğrenme sürecinin etkililiği açısından dikkate alınan akademik başarı (Özgüven, 1998; Cevher, 2017) üzerinde, baskın öğrenme stillerine göre yapılandırılmış öğretimin etkisi incelenmiştir. Araştırma kapsamında sınanan $\mathrm{H}_{1}$ denencesinin kabul edildiği belirlenmiştir. Buna göre, öğrenme stillerine dayalı öğretimin yapıldığı deney grubu öğretmen adaylarının akademik başarıları, öğrenme ortamında herhangi bir manipülasyon yapılmadan derslerin işlendiği kontrol grubu öğretmen adaylarının akademik başarılarından, anlamlı düzeyde yüksek olduğu görülmüştür. Ayrıca bu araştırmanın sonucunda baskın öğrenme stiline göre yapılandırılmış öğretimin, öğretmen adaylarının akademik başarısı üzerinde orta düzeyde etkili olduğu belirlenmiştir. Alanyazındaki araştırmalarda baskın öğrenme stiline göre yapılan öğretimin, öğrenmeyi daha kolay, kalıcı, etkin kılması (Ünlü, Taşkın ve Elbaş, 2015) ve öğrenmeye yönelik tutumu artırması (Özgen, 2012) nedeniyle akademik başarının artmasında doğrudan etkili olduğu (Kazancı, Kazancı, Memduhoğlu ve Sevimli, 2014) belirtilmektedir. Bilgin ve Durmuş (2003) ve Kılı̧ (2002) öğrenme stillerinin öğrenci başarısını belirleyen önemli bir faktör olduğunu rapor etmişlerdir. Alanyazında öğrencilerin öğrenme stilinin belirlenmesinin ve öğrenme stillerine uygun öğretimin yapılmasının akademik başarı üzerinde etkili olduğunun (Bilgin ve Durmuş, 2003; Kılıç, 2002) belirtilmesi bu araştırmanın sonuçlarını destekler niteliktedir. Benzer bulgular, Bayrak ve Bayram (2012), Cengizhan (2007), Cengizhan (2008), Demir ve Usta (2011), Elban (2018), Evin-Gencel (2008), Önder (2006), Özgen ve Alkan (2014), Şeker ve Yılmaz (2011), Yıldız-İkikardeş ve Şentürk (2011) tarafından yapılan araştırmalarda da görülmektedir. John, Shahzadi ve Iqbal Khan (2016) öğretmenlerin, öğrencilerinin tercih ettikleri öğrenme stillerinin farkında olması ve öğrenme stillerine uygun öğretme yöntemini kullanmasının akademik başarı üzerinde olumlu etkisinin olabileceğini belirtmesi bu araştırmanın bulgularını destekler niteliktedir. Araştırmada elde edilen bulgular Grasha-Reichmann öğrenme stilleri modeli ile ders etkinliklerinde çok çeşitli öğretim yöntem ve tekniklerinin uygulanabilirliğini göstermektedir. Öğrenme stillerinin ders etkinliklerinde kalıcı ve bireysel öğretimin gerçeklemesi açısından alternatif bir yol olarak düşünülebilir. Eldeki araştırmanın bulguları alanyazın ile tutarlı olarak öğretmen adaylarının akademik başarılarını artırmada etkili bir çözüm olduğunu göstermektedir. Bu doğrultuda öğretmen yetiştirme programlarında baskın öğrenme stillerinin dikkate alınmasının eğitim ve öğretim süreçlerinde akademik başarının artırılması açısından önemli olarak görülebilir.

Deney grubu öğretmen adaylarının baskın öğrenme stilleri incelendiğinde sırasıyla iş birlikli, bağımsız, rekabetçi, katılımcı, bağımlı ve kaçınan olduğu belirlenmiştir. Azarkhordad ve Mehdinezhad (2016) tarafından yapılan araştırmada da öğretmen adaylarının en yaygın öğrenme stilinin iş birlikli olduğunun belirtilmesi, bu araştırmanın bulgularıyla benzerlik göstermektedir. İş birlikli öğrenme stilinin özellikleri incelendiğinde fikirlerini başkalarıyla paylaşmak ve sınıf ortamında işbirliği yapmaktan hoşlanmaktır (Azarkhordad ve Mehdinezhad, 2016). Bu açıdan iş birlikli öğrenme stilinin özelliklerinin öğretmenlik mesleğiyle uyumlu olduğu söylenebilir. Karakuyu ve Tortop (2010), Tatar, Tüysüz ve İlhan (2008) ve Tüysüz ve Tatar (2008) tarafindan yapılan araştırmalarda öğretmen adaylarının en yaygın öğrenme stillerinin iş birlikli ve rekabetçi olduğu belirlenirken, Aydemir, Koçoğlu ve Karalı (2016), Elban (2018), Sidekli ve Akdoğdu (2018) tarafından yapılan araştırmalarda farklı bulgulara ulaşıldığı görülmektedir. Araştırmalardaki bulgu farklılığının Kaplan ve Kies (1995) tarafından belirtilen öğrenme stillerinin doğuştan gelen parmak izi veya DNA yapısı gibi bir özelliği içermesinden kaynaklanabileceği düşünülmektedir. Bu araştırmanın bulguları sonucunda öğretmen adaylarının eğitimi söz konusu olduğunda, katılımcı ve iş birlikli öğrenme stillerinin özellikleri dikkate alınarak öğretimin yapılandırılması önerilmektedir. Bu öğrenme stillerinin özellikleri arasında araştırma ödevleri ile fikir ve yeteneklerin paylaşarak öğrenildiği tartışma grupları yer almaktadır (Rollins, 2015). Bu bakımdan öğretmen yetiştirme programlarındaki ders içi etkinliklerde ağırlıklı olarak tartışma yöntemi ve içerdiği teknikler ile proje yönteminin kullanılması öğrenmeyi olumlu yönde etkileyebilir.

Araştırmanın öğretmen adaylarının akademik başarılarının, öğrenme stillerine göre anlamlı düzeyde farklılaşmadığı belirlenmiştir. Benzer bulgular Akkoyunlu ve Yılmaz-Soylu (2008), Bahar, Özen ve Gülaçtı (2009), Bahar ve Sülün (2011) ve Kılıç ve Karadeniz’in (2004) araştırmalarında da görülmektedir. Dunn (2000) tarafından yapılan araştırmada öğrencilerin daha başarılı olmaları amacıyla farklı öğrenme stillerinin öğretilmesi ve yapılan etkinliklerin çeşitlendirilmesi önerilmektedir. Bu doğrultuda öğretmen adaylarının baskın öğrenme stillerine göre akademik başarılarının farklılaşmamasının bir nedeni olarak, sınıf ortamında farklı öğrenme stillerine göre yapılan etkinliklerin tüm öğretmen adaylarının akademik başarıları üzerinde dolaylı bir katkı sağlamış olabileceği düşünülmektedir. 
$\mathrm{Bu}$ araştırmanın bulguları Öğretim İlke ve Yöntemleri dersinden elde edilen verilerle sınırlıdır. Bu nedenle gelecekte yapılacak çalışmalarda öğretmenlik meslek bilgisi dersleri içerisinde yer alan farklı disiplinler üzerinde öğrenme stillerinin etkisi incelenebilir. Araştırma kapsamında öğrenme ortamları yapılandırılırken Grasha ve Reichmann öğrenme stilleri modeli kullanılmıştır. Öğretmen eğitiminde farklı öğrenme stilleri üzerine geliştirilmiş model veya yaklaşımlar temele alınarak deneysel araştırmaların yapılması bu konudaki alanyazına katkı sağlayabilir. Araştırmada öğretmen adaylarının tercih ettikleri baskın öğrenme stillerinin akademik başarı üzerinde anlamlı bir etki oluşturmadığı, fakat baskın öğrenme stillerine göre yapılan eğitimin geleneksel yöntemlere göre gerçekleştirilen eğitimden daha etkili olduğu saptanmıştır. Dolayısıyla sınıf ortamında farklı öğrenme stillerine göre yapılan eğitimin, tüm öğrencilerin öğrenmelerine ve akademik başarılarına olumlu katkılar sunması, öğretmen eğitiminde öğrenme stillerinin dikkate alınmasının önemini göstermektedir. Ayrıca bu araştırmanın bulguları sonucunda öğretmenlik mesleğine ilişkin öğrenme stilleri açısından bir sınıflamanın yapılıp yapılamayacağının araştırılması önerilmektedir.

Etik Kurul İzin Bilgisi: Bu araştırma, Fırat Üniversitesi Sosyal ve Beşeri Bilimler Araştırmaları Etik kurulunun /11/07/2018 tarihli 04 sayll kararl ile alınan izinle yürütülmüştür. 


\section{Kaynakça/References}

Akkoyunlu, B., \& Y1lmaz-Soylu, M. (2008). A study of student's perceptions in a blended learning environment based on different learning styles. Educational Technology \& Society, 11(1), 183-193.

Almigbal, T. H. (2015). Relationship between the learning style preferences of medical students and academic achievement. Saudi Med Journal, 36(3), 349-355 doi:10.15537/smj.2015.3.10320

Altun, H. (2016). Ilköğretim matematik öğretmenliği lisans öğrencilerinin türev konusundaki akademik başarıları ile ögrenme stilleri arasındaki ilişkilerin incelenmesi. (Yayımlanmamış yüksek lisans tezi). Dokuz Eylül Üniversitesi, İzmir.

Arslan, H. ve Uslu, B. (2014). Öğretmen adaylarının öğrenme stilleri ile liderlik yönelimleri arasındaki ilişki. Eğitim ve Bilim, 39(173), 341-355.

Aslandağ, B. ve Çetinkaya, G. (2019). Örgütleyici yapı iskelesi tekniğinin öğretmen adaylarının not alma becerilerine ve akademik başarılarına etkisi. Pamukkale Üniversitesi Ĕgitim Fakültesi Dergisi, 45(45), 190210. doi:10.9779/PUJE.2018.229

Aşkar, P. ve Akkoyunlu, B. (1993). Kolb Öğrenme Stili Envanteri. Eğitim ve Bilim, 17(87), 37-47.

Aşkın, Ö. (2006). Öğrenme stilleri ile ilgili elektronik ortamda yayımlanan çalışmaların incelenmesi. (Yayımlanmamış yüksek lisans tezi). Ankara Üniversitesi, Ankara.

Atalay, N. ve Ay, Y. (2016). Fen bilgisi öğretmen adaylarının öğrenme stilleri ile proje performansı ve akademik başarıları arasındaki ilişki. Turkish Studies, 11(3), 277-292 doi:10.7827/TurkishStudies.9507

Atılgan, H. (2006). Test geliştirme. İçinde H. Atılgan (Ed.), Eğitimde ölçme ve değerlendirme (ss. 315-348). Ankara: Anı Yayıncılık.

Aydemir, H., Koçoğlu, E. ve Karalı, Y. (2016). Grasha-Reichmann ölçeğine göre öğretmen adaylarının öğrenme stillerinin değerlendirilmesi. Kastamonu Eğitim Dergisi, 24(4), 1881-1896.

Azarkhordad, F., \& Mehdinezhad, V. (2016). Explaining the students' learning styles based on GrashaRiechmann's student learning styles. Journal of Administrative Management, Education and Training, 12(6), 241-247.

Azizoğlu, N. ve Çetin, G. (2009). 6 ve 7. Sınıf öğrencilerinin öğrenme stilleri, fen dersine yönelik tutumları ve motivasyonları arasındaki ilişki. Kastamonu Eğitim Dergisi, 17(1), 171-182.

Bahar, H. H. ve Sülün, A. (2011). Fen bilgisi öğretmen adaylarının öğrenme stilleri, cinsiyet öğrenme stili ilişkisi ve öğrenme stiline göre akademik başarı. Kastamonu Eğitim Dergisi, 19(2), 379-386.

Bahar, H. H., Özen, Y., \& Gülaçtı, F. (2009). An investigation on academic achievement and learning styles as to branches and gender from faculty of education students'. Ankara University Journal of Faculty of Educational Sciences, 42(1), 69-86.

Bakır, S. ve Mete, H. (2014). Ortaokul öğrencilerinin öğrenme stilleri: Burdur ili örneği. Kırşehir Ĕ̆itim Fakültesi Dergisi, 15(3), 127-145.

Baneshi, A. R., Karamdoust, N. A., \& Hakimzadeh, R. (2013). Validity \& reliability of the Persian version of Grasha-Richmann student learning styles scale. Journal of Advances in Medical Education \& Professionalism, 1(4), 119-124.

Başbay, M. (2013). Epistemolojik inancın eleştirel düşünme ve üstbiliş ile ilişkisinin yapısal eşitlik modeli ile incelenmesi. Eğitim ve Bilim, 38(169), 249-262.

Başbuğ, S. ve Adıgüzel, Ö. (2019). Müzede yaratıcı drama etkinliklerinin öğrencilerin sosyal bilgiler dersindeki başarılarına etkisi. Yaratıcı Drama Dergisi, 14(1), 1-31. doi:10.21612/yader.2019.001

Baykul, Y. (2000). Eğitimde ve psikolojide ölçme: Klasik test teorisi ve uygulaması. Ankara: ÖSYM yayınları.

Bayrak, B. K. ve Bayram, H. (2012). Web ortamında probleme dayalı öğrenme yönteminin farklı öğrenme stiline sahip öğrencilerin akademik başarılarına etkisi. Mustafa Kemal Üniversitesi Sosyal Bilimler Enstitüsü Dergisi, 9(18), 479-497.

Beşoluk, Ş. ve Önder, İ. (2010). Öğretmen adaylarının öğrenme yaklaşımları, öğrenme stilleri ve eleştirel düşünme eğilimlerinin incelenmesi. İlkögrretim Online, 9(2), 679-693. 
Bilgin, İ. ve Durmuş, S. (2003). Öğrenme stilleri ile öğrenci başarısı arasındaki ilişki üzerine karşılaştırmalı bir araştırma. Kuram ve Uygulamada Eğitim Bilimleri, 3(2), 381-400.

Bradford University (2019, Kasım). Index of Learning Styles (ILS) Learning style questionnaire. Retrieved from https://www.bradford.ac.uk/academickills/media/learnerdevelopmentunit/documents/academicskillsresourc es/ effectivelearningstrategies/media-99185-en..pdf

Brown, T., Cosgriff, T., \& French, G. (2008). Learning style preferences of occupational therapy, physiotherapy and speech pathology students: A comparative study. Internet Journal of Allied Health Sciences and Practice, 6(3), 1-12.

Cengizhan, S. (2007). Proje temelli ve bilgisayar destekli öğretim tasarımlarının; bağımlı, bağımsız ve işbirlikli öğrenme stillerine sahip öğrencilerin akademik başarılarına ve öğrenme kalıcılığına etkisi. Türk Eğitim Bilimleri Dergisi, 5(3), 377-403.

Cengizhan, S. (2008). Modüler öğretim tasarımının farklı öğrenme stiline sahip öğrencilerin akademik başarılarına ve öğrenme kalıcılığına etkisinin belirlenmesi. Eğitimde Kuram ve Uygulama, 4(1), 98-116.

Cevher, A. Y. (2017). Öğrenme stilleri konusunda yapılmış akademik çalışmaların incelenmesi: Sistematik derleme. (Yayımlanmamış yüksek lisans tezi). Atatürk Üniversitesi, Erzurum.

Choudhary, R., Dullo, P., \& Tandon, R. V. (2011). Gender differences in learning style preferences of first year medical students. Pakistan Journal of Physiology, 7(2), 42-45.

Coffield, F, Moseley, D, Hall, E., \& Ecclestone, K. (2004). Learning Styles and Pedagogy in Post-16 Learning: A Systematic and Critical Review. London LSRC Reference, Learning \& Skills Research Centre.

Cohen, J. (1988). Statistical power analysis for the behavioral sciences. New York, NY: Routledge.

Demir, B. ve Usta, E. (2011). Eğitim yazılımlarında ön örgütleyicilerin öğrenme stillerine göre akademik başarıya etkisi. Uluslararası İnsan Bilimleri Dergisi, 8(2), 733-749.

Demir, T. (2008). Türkçe eğitimi bölümü öğrencilerinin öğrenme stilleri ve bunların çeşitli değiş̧kenlerle ilişkisi. Uluslararası Sosyal Araştırmalar Dergisi, 1(4), 129-148.

Dikmen, M. ve Tuncer, M. (2018). Bilgi okuyazarlık özyeterliği inanc1, öğretmenlik mesleğine yönelik tutum ve üst biliş düşünme becerileri arasındaki ilişkiler. Elektronik Eğitim Bilimleri Dergisi, 7(13), 73-86.

Dikmen, M., Bahadır, F. ve Akmençe, A. E. (2018). Öğretmen adaylarının öğrenme stillerinin bazı değişkenler açısından incelenmesi. Journal of Educational Reflections, 2(1), 24-37.

Dikmen, M., Tuncer, M. ve Şimşek, M. (2018). Öğrenme stilleri ile öğrenmeye yönelik tutum arasındaki ilişki. Uluslararası Sosyal Araştırmalar Dergisi, 11(57), 388-400. doi:10.17719/jisr.2018.2456

Dobson, J. L. (2010). A comparison between learning style preferences and sex, status, and course performance. Advances in Physiology Education, 34(4), 197-204. doi:10.1152/advan.00078.2010

Dunn, K., \& Dunn, R. (1986). The look of learning styles. Early Years, 8(1), 46-52.

Dunn, R. (2000). Capitalizing on college students' learning styles: Theory, practice, and research. In R. Dunn \& S. A. Griggs (Eds.), Practical approaches to using learning styles in higher education (pp. 3-18). Westport, CT: Bergin \& Garvey.

Elban, M. (2018). Learning styles as the predictor of academic success of the pre-service history teachers. European Journal of Educational Research, 7(3), 659-665. doi:10.12973/eu-jer.7.3.659

Evin-Gencel, İ. (2006). Öğrenme stilleri, deneyimsel öğrenme kuramına dayalı ĕgitim, tutum ve sosyal bilgiler program hedeflerine erişi düzeyi. (Yayımlanmamış doktora tezi). Dokuz Eylül Üniversitesi, İzmir.

Evin-Gencel, İ. (2008). Sosyal bilgiler dersinde Kolb'un deneyimsel öğrenme kuramına dayalı eğitimin tutum, akademik başarı ve öğrenmenin kalıcılı̆̆ına etkisi. İlköğretim Online, 7(2), 401-420.

Felder, R. M., \& Henriques, E. R. (1995). Learning and teaching styles in foreign and second language education. Foreign Language Annals, 28(1), 21-31. doi:10.1111/j.1944-9720.1995.tb00767.x

Felder, R. M., \& Silverman, L. K. (1988). Learning and teaching styles in engineering education. Journal of Engineering Education, 78(7), 674-681.

Felder, R.M., \& Spurlin, J. (2005). Reliability and validity of the index of learning styles: A Meta-analysis. International Journal of Engineering Education, 21(1), 103-112. 
George, D., \& Mallery, M. (2001). Using SPSS for Windows step by step: A simple guide and reference. Boston, MA: Allyn \& Bacon.

Gosling, J. (2004). Introductory statistics: a comprehensive, self-paced, step by step statistics course for tertiary students. Australia, Glebe: Pascal Press.

Graf, S., Viola, S. R., \& Kinshuk, T. L. (2006). Representative characteristics of Felder-Silverman learning styles: An empirical model. In Proceedings of the IADIS International Conference on Cognition and Exploratory Learning in Digital Age (pp. 235-242). Barcelona: IADIS.

Güven, M. ve Kürüm, D. (2006). Öğrenme stilleri ve eleştirel düşünme arasındaki ilişkiye genel bir bakış. Anadolu Üniversitesi Sosyal Bilimler Dergisi, 6(1), 75-90.

Hanafi, A. A. (2019). The effect of students' learning style on their writing achievement. Language-Edu, 8(1), $31-42$

Hein, T. L., \& Budny, D. D. (1999). Teaching to students' learning styles: Approaches that work. In_Proceedings of FIE'99 Frontiers in Education. 29th Annual Frontiers in Education Conference. Designing the Future of Science and Engineering Education (IEEE Cat. No. 99CH37011 (Vol. 2, pp. 12C1-7). San Juan, Puerto Rico: IEEE.

Howitt, D., \& Cramer, D. (1997). A guide to computing statistics with SPSS for Windows. Simon \& Schuster, Inc. London: Prentice-Hall.

Huglin, L. M. (2003). The relationship between personal epistemology and learning style in adult learners. Dissertation Abstracts International, 64(3), 759.

John, A., Shahzadi, G., \& Igbal Khan, K. I. (2016). Students' preferred learning styles \& academic performance. Sci. Int. (Lahore), 28(4), 337-341.

Kamışl1, H. ve Özonur, M. (2019). Students' learning styles in vocational education. International Journal of Curriculum and Instruction, 11(1), 209-220.

Kaplan, E. J., \& Kies, D. A. (1995). Teaching styles and learning styles. Journal of Instructional Psychology, 22(1), 29-34

Karakuyu, Y. ve Tortop, H. S. (2010). Öğretmen adaylarının öğrenme stillerinin fizik dersine yönelik tutum ve başarılarına etkisi. Afyon Kocatepe Üniversitesi Fen ve Mühendislik Bilimleri Dergisi, 10(1), 47-55.

Karasar, N. (2009). Bilimsel araştırma yöntemi (19. bask1). Ankara: Nobel.

Kaya, H. ve Akçin, E. (2002). Öğrenme biçemleri/stilleri ve hemşirelik eğitimi. Cumhuriyet Üniversitesi Hemşirelik Yüksek Okulu Dergisi, 6(2), 31-36.

Kazancı, F., Kazanc1, E. E., Memduhoğlu, H. B. ve Sevimli, Ş. (2014). Tıp ve diş hekimliği öğrencilerinin öğrenme stillerinin karşılaştırılması. Atatürk Üniversitesi Diş Hekimliği Fakültesi Dergisi, 24(1), 67-73.

Keefe, J. W. (1979). Learning style: An overview. In J. W. Keefe (Ed). NASSP's Student Learning Styles: Diagnosing and Prescribing Program (pp. 1-17). Reston, VA: National Association of Secondary School Principals.

Kılıç, E. (2002). Web temelli ögrenmede baskın öğrenme stilinin öğrenme etkinlikleri tercihi ve akademik başarlya etkisi. (Yayımlanmamış yüksek lisans tezi). Ankara Üniversitesi, Ankara.

Kılıç, E. ve Karadeniz, Ş. (2004). Cinsiyet ve öğrenme stilinin gezinme stratejisi ve başarıya etkisi. Gazi Üniversitesi Gazi Ĕgitim Fakültesi Dergisi, 24(3), 129-146.

Kılıç, G. (2011). İlköğretim 6. Sinıf öğrencilerinin öğrenme biçemleri ile ilköğretim okullarında görevli Ingilizce ögretmenlerinin öğrenme ve ögretme biçemlerinin belirlenmesi. (Yayımlanmamıș yüksek lisans tezi). Ankara Üniversitesi, Ankara.

Kolb, D. A. (1984). Experimental learning: Experience as the source of learning and development. Englewood Cliffs, NJ: Prentice Hall, Inc.

Kolb, D. A. (1988). Learning styles and disciplinary differences. California Management Review, 18(3), $22-31$.

Kösece, P., Üredi, L. ve Akbaşlı, S. (2015). Eğitim fakültesi sınıf öğretmenliği bölümü öğrencilerinin kişilik tipleriyle öğrenme stilleri arasındaki ilișkinin incelenmesi. Turkish Studies, 10(7), 675-688.

Lu, H., Jia, L., Gong, S. H., \& Clark, B. (2007). The relationship of Kolb learning styles, online learning behaviors and learning outcomes. Journal of Educational Technology \& Society, 10(4), 187-196. 
Mihai, I. A. (2017). Theoretical and practical aspects concerning the teaching evaluation process. The subjective evaluation. International Journal of Educational Theory and Practice (IJETP), 4(1), 37-50.

Miles, D. G. (2004). An investigation of learning style preferences and academic self-efficacy in first-year college students. (Unpublished dissertation). Clemson University, South Carolina.

Ozan, C., Karabacak, N., Kızıltaş, E. ve Küçükoğlu, A. (2017). Öğretmen adaylarının öğrenme stilleri ile öğrenme yaklaşımları tercihleri arasındaki ilişkinin incelenmesi. Uluslararası Türkçe Edebiyat Kültür Eğitim Dergisi, 6(3), 1818-1843. doi:10.7884/teke.4002

Önder, F. (2006). Fizik ĕ̆itiminde öğrenme stillerine dayalı öğretim yöntemlerinin öğrenci başarısı üzerindeki etkileri. (Yayımlanmamış doktora tezi). Dokuz Eylül Üniversitesi, İzmir.

Özgen, K. (2012). Yapılandırmacı öğrenme yaklaşımı kapsamında, öğrencilerin öğrenme stillerine uygun ögrenme etkinlikleri geliştirilmesi: Fonksiyon ve türev kavramı örneklemesi. (Yayımlanmamış doktora tezi). Dokuz Eylül Üniversitesi, İzmir.

Özgen, K. ve Alkan, H. (2014). Yapılandırmacı öğrenme yaklaşımı kapsamında, öğrencilerin öğrenme stillerine uygun öğrenme etkinliklerinin akademik başarı ve tutuma etkileri: Fonksiyon ve türev kavramı örneklemesi. Türk Bilgisayar ve Matematik Eğitim Dergisi, 5(1), 1-38.

Özgür, D. S. (2011). Türetimci çoklu ortamın ögretmen adaylarının ögrrenme stillerine göre başarl, tutum ve kalıcılı̆̆a etkisi ile ögretmen adaylarının ortama yönelik görüşleri. (Yayımlanmamış yüksek lisans tezi). Hacettepe Üniversitesi, Ankara.

Özgüven, İ. (1998). Bireyi tanıma teknikleri. Ankara: Pegem Yayınları.

Özpolat, E. ve Akar, G. B. (2009). Automatic detection of learning styles for an e-learning system. Computers \& Education, 53(2), 355-367. doi:10.1016/j.compedu.2009.02.018

Pehlivan, Z. (2010). Beden eğitimi öğretmen adaylarının fiziksel benlik algıları ve öğretmenlik mesleğine yönelik tutumlarının analizi. Eğitim ve Bilim, 35(156), 126-141.

Puji, R. P. N., \& Ahmad, A. R. (2016). Learning style of MBTI personality types in history learning at higher education. Social Sciences and Economics, 3(6), 289-295. doi:10.27512/sjppi-ukm/ses/a13122016

Retrosi, G., Morris, M., \& McGavock, J. (2019). Does personal learning style predict the ability to learn laparoscopic surgery? A pilot study. Journal of Laparoendoscopic \& Advanced Surgical Techniques, 29(1), 98-102. doi:10.1089/lap.2018.0196

Riechmann, S. W., \& Grasha, A. F. (1974). A rational approach to developing and assessing the construct validity of a student learning style scales instrument. The Journal of Psychology, 87(2), 213-223. doi:10.1080/00223980.1974.9915693

Rollins, M. (2015, Ocak). Learning style diagnostics: The Grasha-Riechmann Student Learning Styles Scale. Retrieved from https://elearningindustry.com/learning-style-diagnostics-grasha-riechmann-studentlearning-styles-scale

Russell, B., \& Purcell, J. (2009). Online research essentials: designing and implementing research studies. San Francisco, CA: Jossey-Bass, A Wiley Imprint.

Sarıtaş, E. ve Süral, S. (2010). Grasha-Reichmann öğrenme ve öğretme stili ölçeklerinin Türkçe uyarlama çalışması. E-Journal of New World Sciences Academy, 5(4), 2162-2177.

Shirazi, F., \& Heidari, S. (2019). The relationship between critical thinking skills and learning styles and academic achievement of nursing students. The Journal of Nursing Research, 27(4), 1-7. doi:10.1097/jnr.0000000000000307

Sidekli, S. ve Akdoğdu, E. (2018). Öğrenme stillerinin sınıf öğretmeni adaylarının akademik başarılarını yordama gücü. Hacettepe University Eğitim Fakültesi Dergisi, 33(2), 503-517. doi:10.16986/HUJE.2017027919

Singh, V. (2017). Exploring the relationship between cognitive style and learning style with academic achievement of elementary school learners. Educational Quest-An International Journal of Education and Applied Social Sciences, 8(spl), 413-419. doi:10.5958/2230-7311.2017.00084.8

Süral, S. ve Sarıtaş, E. (2015). Sınıf öğretmenliği öğretmen adaylarının fen ve teknoloji öğretimi dersindeki öğrenme stilleri ile akademik başarıları arasındaki ilişki. Recep Tayyip Erdoğan Üniversitesi Sosyal Bilimler Dergisi, 1(1), 31-44. 
Şeker, M. ve Yılmaz, K. (2011). Sosyal bilgiler öğretiminde öğrenme stillerinin kullanılmasının öğrencilerin öğrenme düzeyleri üzerindeki etkisinin incelenmesi. Kastamonu Ĕ̆itim Dergisi, 19(1), 251-266.

Taşpınar, M. (2017). Sosyal bilimlerde SSPS uygulamalı nicel veri analizi. Ankara: Pegem Akademi.

Tatar, E., Tüysüz, C. ve İlhan, N. (2008). Kimya öğretmeni adaylarının öğrenme stillerinin akademik başarılarıyla ilişkisi. Mustafa Kemal Üniversitesi Sosyal Bilimler Enstitüsü Dergisi, 5(10), 185-192.

Tekin, H. (2010). Eğitimde ölçme ve değerlendirme. Ankara: Yargı Yayınevi.

Tomlinson, C. A. (2007). Öğrenci gereksinimlerine göre farklılaştırılmış eğitim. (DİYE Kültürlerarası İletişim Hizmetleri, çev.). İstanbul: Redhouse Eğitim Kitapları.

Tuncer, M. ve Dikmen, M. (2019). A contribution to discussions regarding learning style: the changes occurring within three weeks of time. Journal of Educational Issues, 5(1), 30-43. doi:10.5296/jei.v5i1.14250

Tuncer, M., Dikmen, M., \& Akmençe, A. (2018). Investigation of higher education students' learning styles and attitudes towards mobile learning according to various variables. International Journal of Social Sciences and Education Research, 4(3), 433-446.

Tüysüz, C. ve Tatar, E. (2008). Öğretmen adaylarının öğrenme stillerinin kimya dersine yönelik tutum ve başarılarına etkisi. Mustafa Kemal Üniversitesi Sosyal Bilimler Enstitüsü Dergisi, 5(9), 97-107.

Usta, A. (2006). İlköğretim fen bilgisi derslerinde ögrenme stillerine dayalı öğretim etkinliklerinin öğrenci erişi ve tutumlara etkisi. (Yayımlanmamış doktora tezi). Selçuk Üniversitesi Konya.

Uzuntiryaki, E., Bilgin, I. ve Geban, Ö. (2004). The relationship between gender differences and learning style preferences of pre-service teachers at elementary level. Hacettepe University Journal of Education, 26(261), 182-187.

Uzuntiryaki, E., Bilgin, N. ve Geban, Ö. (2003). The effect of learning styles on high school students' achievement and attitudes in chemistry. Annual Meeting of the National Association for Research in Science Teaching, Philadelphia, PA, (ERIC Document Reproduction Service No. ED 475483).

Ünlü. H., Taşkın, S. ve Elbaş, N. Ö. (2015). Sağlık bilimleri fakültesi hemşirelik bölümünde eğitim gören öğrencilerin öğrenme biçemleri. International Journal of Social Sciences and Education Research, 1(4), 1436-1450.

Vizeshfar, F., \& Torabizadeh, C. (2018). The effect of teaching based on dominant learning style on nursing students' academic achievement. Nurse Education in Practice, 28, 103-108. doi:10.1016/j.nepr.2017.10.013

Yıldız, Ş. ve Beşoluk, Ş. (2019). Fen bilimleri dersinde probleme dayalı öğretim yaklaşımının öğrencilerin problem çözme becerilerine ve akademik başarılarına etkisinin incelenmesi. Journal of Individual Differences in Education, 1(1), 50-68.

Yıldız-İkikardeş, N. ve Şentürk, F. (2011). Öğrenme ve öğretme stillerinin 7. sınıf öğrencilerinin matematik başarısı üzerine etkisi. Necatibey Eğitim Fakültesi Elektronik Fen ve Matematik Ĕgitimi Dergisi, 5(1), 250276.

Yükseköğretim Kurulu [YÖK]. (2019, Ocak). Yeni Öğretmen Yetiştirme Lisans Programlarl. https://www.yok.gov.tr/kurumsal/idari-birimler/egitim-ogretim-dairesi/yeni-ogretmen-yetistirme-lisansprogramlari adresinden elde edildi.

Zarrabi, F. (2017). Investigating the relationship between learning style and metacognitive listening awareness. International Journal of Listening, 31(1), 1-13 doi:10.1080/10904018.2016.1276458 